\title{
Любимова Т.Б. Мы сами и факт
}

Аннотация: Проблема авторства в искусстве является специфически современной проблемой, не существовавщей в традиционной культуре. Автор нередко прячется за своими персонажами. Это связано с побудительными причинами творчества, которые могут быть поняты на психологическом уровне рассмотрения, когда переживание или событие в судъбе автора оказываются точкой поворота к раскрытию себя или в себе высшего начала. Поэтому эта же проблема может быть рассмотрена и на метафизическом уровне. Этот аспект творчества А.С. Пушкина, Н.В. Гоголя, У. Шекспира при метафизической точке зрения выводит нас к новым смыслам искусства и авторства в нем. Поясняющими моментами служат примеры из других видов искусства - кино, музыки. Методом исследования в данном случае может быть квази художественное построение самого исследования. При этом происходит внутренняя перекличка смысловых точек поворота в самом изложении проблемы. Основными выводами статьи является то, что авторство произведения искусства имеет сложное строение, что создает определенный объем, требующий постоянной смены обзора, обращения к темам, косвенно относящиеся к главной теме исследования. Этот особый аспект рассмотрения авторства является новым для философии и эстетики. Проблема авторства есть специфически современная проблема культуры.

Ключевъе слова: Автор, персонажи, сцена, публичное пространство, гений, фактичность, двойственность, произведение искусства, русская культура, язык страсть.

Review: Problem of authorship in art is a modern problem which had not existed in traditional culture. An author often hides behind own characters. This happens due to the motivation reasons of creativity (which can be understood on a psychological level of analysis) when an emotional move or event in the author's fate becomes the turning point for revealing own Self or some internal divine spirit. Therefore, this problem can be regarded on the metaphysical level as well. Metaphysical perspective on the works by Alexander Pushkin, Nikolai Gogol, William Shakespeare takes us to some new meanings of art and authorship. The examples from other fields of art: cinema, music-provide additional arguments in the article. The suggested method of research - quasi artistic construction of the study itself. In this case an interconnection between semantic turning points occurs in the course of the text.The main conclusions of the paper are: that the authorship of a work of art has a complex structure, which creates a certain amount, which requires constant change of view, referring to topics indirectly related to the main topic of research. This particular aspect of the consideration of authorship is a new philosophy and aesthetics. The problem of authorship is a specifically modern problem of culture.

Keywords: A work of art, duality, factuality, genius, public space, stage, characters,, Author, Russian culture, language passion.

Автор телесных форм нетелесен. Автор звуков не воспринимаем на слух, автор цветов не виден глазу, автор вкусов не воспринимаем на вкус

(Ле-цзы).

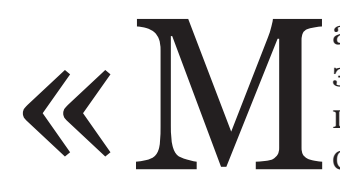
адам Бовари - это я», сказал Флобер. Нередко гений прячется за каким-то из своих персонажей. Вообще, отношение персонажей и автора не похоже на господство хозяина над слугами, начальника над подчиненными; это не есть осуществление власти - воображаемой, конечно, - над воображаемыми же людьми, или над материалом, сопротивление которого преодолевается в творчестве, или, наконец, над стихиями, или качествами - цветом, звуком и т.п. Авторство не есть сублимация комплекса власти или какой-другой деформации психики, не есть это и пустая игра. Все это присутствует, но не составляет центрального нерва и скры- 
того мотора творчества. «Шесть персонажей в поисках автора» (пьеса Л. Пиранделло) точно указывают на скрытую точку. В этой пьесе, как ясно из названия, персонажи по отношению к произведению и к его автору суть элемент движущий, а процесс творчества есть реализация желания персонажей быть воплощенными... на сцене, разумеется. Мадам Бовари избрала Флобера, чтобы он воплотил ее в жизни книги, и он дал ей жизнь, и в то же время он творец самого себя в меру таланта.

А верно ли, что подражание Творцу есть мотор или мотив творчества? Вовсе не обязательно, даже редкий случай, чтобы артист, художник или писатель, поэт руководствовались подобным мотивом. Такая мысль была бы скорее тормозом, нежели двигателем.

Психологически, исходя из фактов жизни, нередко можно найти, какой именно персонаж дает тайное убежище своему автору. Чем гениальнее автор, тем парадоксальнее и в то же время очевиднее его укрытие. Пушкин, вероятно, прятался за Татьяной, потому что в ней есть достоинство перед лицом непобедимого Эроса. Нет, не за Онегиным, хотя, возможно, что за ними обоими вместе; поскольку в паре, в двойственности разгадка этого самого таинственного бога любви; настоящего автора этой истории который и не скрывается вовсе; остальные персонажи остаются на большей дистанции.

Чем больше творческая личность находит в себе божественных даров, тем более одинокой она себя чувствует среди людей, ее подлинные «близкие и родные» - это гении того же масштаба; они принимают друг от друга дар гения: И. Стравинский свой опус «Поцелуй феи» посвятил П. И. Чайковскому, музыку которого он обожал, как тот в свою очередь обожал музыку Моцарта. Это обожание нельзя объяснить простым предпочтением или стилевым влиянием, исторической преемственностью. Это передача гения в смысле духовной сущности, печати эгрегора (причастие от реческого глагола $\varepsilon \gamma \varepsilon i \rho \omega-$ пробуждать, возбуждать, исцелять, воскрешать) или, говоря современным языком, некого информационного концентрата в едином информационном поле. Музыка сама находит своего избранника. Мы же привыкли объяснять всё влияниями, а можно объяснить это «избирательное сродство» тем, что в информационном поле, проявление которого называют культурой, существует вполне реальное образование, «гений», которое проявляется в жизни конкретных чувствительных к нему людей. Поэтический дар Пушкина есть отражение, как представляется, того же гения, точнее сказать, его печать. Культура вмещает в себя множество таких печатей, образующих как бы водораздел между образованиями в тонком мире и их воплощениями в физическом. Нельзя человека натренировать «быть гением», сделать харизматиком при помощи каких-либо «духовных» практик. Все равно будет что-то не то.

Пушкин, я думаю, чувствовал разрыв между собою частным человеком, и собою же, тем человеком, которого фея погладила по голове. «И с отвращением читая жизнь мою, я трепещу и проклинаю. И горько жалуюсь, и горько слезы лью, но строк печальных не смываю». Однако несчастливость неприлична, в ней нет высокого достоинства. Честолюбивый человек ее скрывает, а принципиально ее скрыть невозможно. Наше эго всегда несчастно, потому что оно ненасытно: «Не насытится око зрением, не наполнится ухо слушаньем». И невозможно утолить жажду эго не только в смысле чувственности, но что еще важнее, жажду в смысле эмоций, чувств, мысли, желаний. Отсюда «страсти роковые», причем не только коренящиеся в жизни тела и ума, но и страсти, в которые втягивается душа. Бесстрастие души (а-патия), однако, означает, что она и вовсе не живет. Жизнь души есть претерпевание времени, а «время - не более как мучение» (А. Грин). И поэт вдохновляется несчастьем любви, которая и есть жизнь души (поэзия всегда есть что-то о любви). Несчастье, когда она вне и без судьбы. А у кого она бывает счастьем? Несчастье унизительно. Пресловутый донжуанский список Пушкина, сам факт так называемого донжуанства есть тому свидетельство. С одной стороны, эта литературная фигура обозначает собою мечту о победе над женским началом вообще, об укрощении женской энергии. Вся культура, если счесть религию ее информационно-энергетическим ядром, пронизана подавлением этого начала. Так называемый декалог (10 заповедей Моисея) в тексте ВЗ продолжается перечислением всех других заповедей (предписаний), одиннадцатая из которых 
гласит: встретишь ворожею, убей ее. Это явный запрет на проявление женской духовной энергии и соответствующего ей знания. Такой запрет присущ всем религиям в силу того, что социумы исторического времени существуют в режиме готовности воевать, война - дело кшатриев, восставших против брахманов, принцип которых - созерцание (в терминах индуизма). Но с другой стороны, не на уровне принципа, а на уровне индивидуальной психологии, Дон-Жуан преследует любовь; сама идея этого персонажа, есть несчастье любви, он бежит за тенью любви (или от нее) и ни в ком не находит подлинника, только тени. Вообще, это романтическая фигура странника и скитальца. А скиталец бежит от чего-то и преследует что-то. Бежит от себя и во след себе же убегающему, или еще точнее, бежит за временем (как таковым, не обязательно утраченным). Как только этот герой встречается со своей любовью (судьбой, парой, Донной Анной), то сталкивается с Каменным Гостем («Тяжело пожатье каменной десницы»), ужасной судьбой, самим собой. И тогда, как универсально выразился А. Платонов, «жить некуда». Наверное, к этому в личности поэта добавилось и еще многое, уязвленное самолюбие, чувство собственного превосходства, не находящее ожидаемого признания. Признавался талант, а не все, на что претендует личность поэта; как и всякая личность, она требует для себя универсального признания. Несчастная любовь изображает собою символически непризнание полноты себя ${ }^{1}$. Внутреннее чувство своего «CAMO» (SOI), то есть Бога в нас самих, присущее по природе любому автору, требовало высшего достоинства, причем достоинства во всей полноте своего существа, а не только признания окружением, «толпой» и по мелочам. Значит, требовало не только признания поэтического дара ведь это дар, а не личное достоинство, - но и признания значимости всей проживаемой жизни. Если дар заключить в скобки, то остаются самые обычные человеческие качества, которые взятые сами по себе никакого гения не порождают. Дар - дается, исток его бессмысленно искать в биогра-

\footnotetext{
${ }^{1}$ Если произведение есть голограмма полноты жизни автора, то ось, на которой оно держится, есть нереализуемая любовь между собой маленьким «я»и неуловимым собою же - богом.
}

фии, в психологии, в них только условия его проявления. Но мы, в своем поклонении гениальности вообще, одобряем и это обыкновенное, перенося свое восхищение гением и даром, на его временного носителя, держателя акций, так сказать. Хотя они далеки друг от друга, как небо и земля. Ведь «средь детей ничтожных мира, быть может, всех ничтожней он», (это пока не призовет поэта к священной жертве Аполлон). Ясное чувство своей ничтожности, ничтожности своего маленького «я», soi, при чувстве божественности дара - вот глубинная причина, на мой взгляд, почему автор таится за своими персонажами, томясь в поисках самого себя, почему он выставляет толпе вместо себя куклу для восхищения и любви, как Наташа Ростова совала в детской комнате куклу для поцелуя молодому человеку (Борису). Конечно, «башня из слоновой кости» Флобера не для Пушкина, который хотел с достоинством претерпеть недостаточность индивидуального существа. В паре «Татьяна-Евгений», кроме сентиментального и внешнего есть нечто трансцендентное и внутреннее. Она, Татьяна, утверждает достоинство свободной воли по отношению к простоте страсти, это своего рода освобождение от мертвой хватки, принудительности страсти, сковывающей волю. Эрос - бог, его природа божественна, но обращен он своим ликом к нам, обычным существам, встречается только с частным. Она, Татьяна, таким образом, делает шаг к «любви в себе», то есть $\boldsymbol{\kappa}$ самой себе. Он, Евгений, - непосредственное несчастье той же любви, без освобождения, то есть крах экзистенции, никуда не ведущий. Бедный Евгений не получил ничего от этого важного события своей жизни, не получил главного - душа претерпела несчастье, но не раскрылась. Это не история любви, как обычно читается роман, а история Души. Одна душа восходит, а другая - нет, не раскрывается, она остается не познавшей ${ }^{2}$. Возможно, что

\footnotetext{
${ }^{2}$ Совсем из другой оперы - но я приведу пример ради прояснения идеи, к тому же произведения так называемого первого ряда буквально затоптаны интерпретациями, мы же возьмем не затоптанный образец. Это фильм еще советского времени «Три тополя на Плющихе». На поверхности просто сентиментальный сюжет, коротенькая история о неудавшейся любви. Так фильм и читался бы, если бы не последняя сцена, в которой Татьяна Доронина (исполнительница главной роли)
} 
моя интерпретация - метафизики любви в приложении к конкретному и простому, на первый взгляд, случаю - кажется несколько искусственной, слишком платонической. Но Пушкин не был бы гением, если бы имел в виду просто сентиментальную историю или «энциклопедию русской жизни». Он, скрывая, открыл самую чувствительную точку души, а П. И. Чайковский сверх гениально завершил интонацией «Нет! Нет!» в последней сцене оперы то, что в намеке было сказано поэтом. Композитор и сам выстрадал эту интонацию. Кстати, метафизика любви самой короткой формулой высказана У. Шекспиром в «Ромео и Джульетте». Не только вражда, как внешнее обстоятельство, социальное то есть, но и сама судьба - здесь в облике случая, - есть роковое препятствие тому, чтобы любовь была в этом мире. Да и трудно себе вообразить любовь Ромео и Джульетты в старости, как невозможно себе представить их стариками (не в смысле служения родовому потоку, а в абсолютном, если можно так сказать, смысле, заключающем в себя всю полноту этого непостижимого дара и проклятия богов). Любопытно, что в обоих случаях присутствует убийство, а с точки зрения невидимых пружин судьбы главное это, а вовсе не сила чувств, желаний героев или обстоятельств. Несчастье любви, конечно, не в том, что она может быть неразделенной или не взаимной, а в том, что наше маленькое «я» любит в другом SOI (свою божественную сущность), коим этот другой вовсе не является. Мистики находили решение в том, чтобы в себе самом любить это САМО, божественную сущность. Такая любовь есть познание, а, как говорится, чтобы познать Небо, надо стать Небом, чтобы познать Бога, надо стать Богом, то есть умереть.

Но художник не хочет умирать, даже в таком возвышенном смысле. «Я жить хочу, чтоб мыслить и страдать», а лучше сказать, «чтоб мыслить и любить, мыслить и мечтать», или мечтать о возвышающей любви. Любовь во «всенародном» смысле, центрированная на физиологии, не возвышает. Но

каким-то неуловимо лица не общим выражением кажет нам, что душа обрела бесценный духовный опыт, она, изменившись, преобразилась, хотя обстоятельства жизни остались те же, а ее преображения даже никто и не заметил. То есть это тоже история Души, а не любви в обычном понимании. и она худо-бедно восполняется по необходимости. Чем же? Моралью, социальными установлениями (семейными и другими), стандартами культуры, подчинение которым и следование им делают обитаемой эту рискованную и непроясняемую светом разума сферу. Тогда ясно, почему не открыто, а в шапке-невидимке живет автор в своем произведении, почему он прячется, перекрывая вымыслом («над вымыслом слезами обольюсь») не пересекаемую линию внутри самого себя, отделяющую soi oт SOI.

Этот разрыв может быть и не в связи с несчастием любви. Н. В. Гоголь тоже прячется от несчастия судьбы. Художественное произведение - это и путешествие, и странствование, и скитальчество, и даже укрытие на пути. Хотя писатель и реально укрывался в любимой Италии, откуда он мысленно путешествовал по воображаемой России, снежной и страшной.

Ради какого же великого дела открывает пред нами душу этот необычный человек? На поверхности произведения везде выступает смех, единственное «благородное лицо», благородство которое скрыто от глаз зрителя! Ну, конечно, там же и слезы, экзистенциальные слезы, если сказать красиво. Чаще всего, когда в текстах наших философов встречаешь звонкие слова, наподобие трансценденции, экзистенции и прочие того же сорта, а авторы этих текстов не имеют соответствующего душевного опыта, то остается неприятное чувство, что слышишь какой-то пустой трескучий звук. Но когда у автора есть реальный опыт души, то и без употребления красивых слов от текста веет и холодком трансценденции и жаром экзистенции.

Может быть, предчувствие такой ужасной и ранней смерти есть разгадка неотразимого и пугающего обаяния гения Гоголя? Недаром же даже в веселых «Вечерах...» гробы поминаются довольно часто. Но нет, дело идет о жизни и о самочувствии в ней.

Многие любители творчества Гоголя, читая его произведения, получают большое удовольствие от того, что предаются совместному с автором, как им кажется, осуждению всего и вся. Ведь все, куда ни кинь взгляд, ужасно и безобразно. Коллективное осуждение, круговая порука, за счет которой и сам как будто чуть приподнимаешься над всеми. Им кажется, что Гоголь кого-то обличает, а человеку приятно, что можно 
обличать, разумеется, с чувством собственного превосходства, забывая самые важные слова «над собой смеетесь» и горечь, скрытую в этих словах. Так ведь Гоголь над собой смеялся! Если бы не было этого обращения на самого себя, то был бы СалтыковЩедрин, обличитель и ненавистник.

Может быть, Гоголь прятался за единственным благородным лицом, смехом? Как бы не так! К «Ревизору» есть два разъяснения, помогающих искать автора за разговорами о пьесе. Из них ясно, как сложно чувствует себя актер на сцене и после спектакля. Но где же автор? Может быть, это тот «автор», который произносит в «Театральном разъезде» сентенции относительно роли искусства, расшифровывает для нас эстетические взгляды самого Гоголя? Это было бы слишком просто для такого изворотливого гения. Нет, это тоже театральная маска. Ближе к истине высказанная идея в «Развязке Ревизора»: «Не о красоте нашей должна быть речь, но о том, чтобы в самом деле наша жизнь, которую привыкли мы почитать за комедию, да не кончилась бы такой трагедией, какою не кончилась эта комедия, которую только что сыграли мы. Что ни говори, но страшен тот ревизор, который ждет нас у дверей гроба. Будто не знаете, кто это ревизор? Ревизор этот наша проснувшаяся совесть, которая заставит нас вдруг и разом взглянуть во все глаза на самих себя. Перед этим ревизором ничто не укроется, потому что по истинному высшему велению он послан, и возвестится о нем тогда, когда уже и шагу нельзя будет сделать назад. Вдруг откроется перед тобою, в тебе же откроется такое страшилище, что от ужаса подымется волос. Лучше же сделать ревизовку всему, что ни есть в нас в начале жизни, а не в конце ее - на место пустых разглагольствований о себе и похвальбы собой, да побывать теперь же в безобразном душевном нашем городе, который в несколько раз хуже всякого другого города, - в котором бесчинствуют наши страсти, как безобразные чиновники!». Хлестаков - светская совесть, продажная. «Смотрите, как всякий чиновник с ним в разговоре вывернулся ловко и оправдался, - вышел чуть не святой. Думаете, не хитрей всякого плута-чиновника каждая страсть наша? И не только страсть, даже самая пустая, пошлая какая-нибудь привычка. Так ловко перед нами вывернется и оправдается, что еще почтешь ее за добро- детель, и даже похвастаешься перед своим братом, и скажешь ему: "Смотри, какой у меня чудесный город, как в нем все прибрано и чисто!”. Лицемеры - наши страсти, говорю вам, лицемеры, потому что сам имел с ними дело» [2, 160-162]. В глазах этого ревизоpa, освещающих страсти нашего города-души, предстанет нам самим неведомая наша сущность, и тогда авторство есть ужасание перед самим собой, автор - мое маленькое эго перед лицом истины, неведомого Ревизора. Конечно, мы не верим этим сентенциям Гоголя, потому что пафос, потому что слишком возвышенно, это дозволено проповедникам в рясах, в чалмах, во всевозможных причудливых одеяниях, а не простому смертному, тем более смешному человеку, клоуну, В молодости Гоголь мечтал на сцене исполнять роли романтических героев, он обладал большим актерским, но только комическим даром; особенно ему удавались роли комических старух. Но возвышенная душа не может стать другой, и сколько раз он не пытался напрямик высказывать высокие мысли, ничего, кроме осуждения и смеха он встретить не мог. И, в конце концов, смех стал его Каменным Гостем.

Мотором авторства бывают если не обязательно или не всегда страсти, то, во всяком случае, события и память о них. И события личной жизни, в особенности. Их же надо изживать, а лучший и самый безболезненный способ - это творчество, путешествие во внутреннем пространстве своего мира. Поэтому я делаю рискованный вывод, что в данном случае «автор» раздваивается. Это и посредник между эго и Ревизором, но это и посредник между страстями (событиями) и самим собою. Гоголь, думаю, искренне не ставит себя в позицию превосходства. Он в себе преследует «чёрта», изворотливого подражателя, карикатуру на достоинства человека. То есть решает добраться до высоты от противного: в себе он чувствует присутствие бесовщины, изощренной и неуловимой, и ее надо победить. Без этого момента - одновременно и «чёрта» и тут же тайного идеала и даже тайны идеала - без этого невозможно уловить особую тональность, можно даже сказать, томительность страдания в жизни этой души. Без этого Гоголь есть, как выразился В. В. Розанов, «ужасный хохол». Конечно, эти слова, розановские, «чур, чур меня!» относятся к внутреннему демону, превращающему любой 
идеал в посмешище. Автор перед этим невидимым врагом - простак. Гоголя нередко считают романтиком, но для романтиков демон (в качестве противника Бога) эстетизируется. Гоголь сражается с этим темным началом всерьез со смехом, который звучит не столь весело, как бы хотелось автору.

Поэтому и сам идеал подан тоже с самонасмешкой, ведь дух тьмы может укрыться где угодно, даже спрятаться за идеалом. А насмешка, тем более над собой, как правило, есть знак бессилия. Мы помним, как неудачно был подан «идеал» Гоголем в его первой, еще романтической поэме. Хорошо, что его все-таки не подвело уникальное чувство истины. Он опередил насмешников, подал стремление к идеалу в смешном виде и стал выражать идеал апофатически, через разные ситуации краха надежд и желаний. Вторая составная нашего автора не может быть чем-то исключительным, напротив, она должна быть простоватой и даже глуповатой, а кто нам самым смешным образом представил «идеал» человека? Это Агафья Тихоновна. За этим образом Гоголь и спрятался. Почему? Во-первых, автор любит получше прятаться, а уж за женским образом сам Бог велел (вспомним Флобера)!

Конечно, есть авторы, которые не прячутся совсем, но это менее всего интересный случай, при котором эго доминирует, но не глубоко, не столкнувшись еще с последними пределами.

Еще раз, почему Агафья Тихоновна? Потому что это крах «идеала», а смех исцеляет. В «Женитьбе» есть такая мечта о смешном совершенстве, знаменитое: «Уж как трудно решиться, так просто рассказать нельзя, как трудно. Если бы губы Никанора Ивановича да приставить к носу Ивана Кузьмича, да взять сколько-нибудь развязности, какая у Балтазара Балтазарыча, да, пожалуй, прибавить к этому еще дородности Ивана Павловича, - я бы тогда тотчас бы решилась»\{2, 205\}. Нет, конечно, Гоголь не так наивен. А будто, в самом деле, не так? Да так, именно так! Просто он о себе это знает и смеется над собой. «Женитьба» заканчивается словами свахи (надо не забывать, что свадьба и похороны суть одно и то же) - тоже весьма знаменитыми. В ответ на упреки, она отвечает, что знаменательно: «Еще если бы в двери выбежал, - ино дело, а уж коли жених да шмыгнул в окно, уж тут, просто, мое почтение» [2, 234]. Предполагаемое неудачное сватовство Гоголя, возможно, имеет отношение к мотиву создания этой пьесы. Надо же было как-то выпутаться с честью из глупой ситуации, то есть над самим собой посмеяться, тем самым ускользнуть от осуждения других, ведь дважды за одну ошибку не наказывают. Защитная роль самоиронии почти всегда очевидна. Доподлинно неизвестно, был ли факт неудачного сватовства, но сама возможность этого факта значима; если его не было, то с точки зрения драматургии жизненного пути он туда напрашивается; то есть «окошко» должно было оказаться и в судьбе Гоголя.

Однако не весь автор спрятался в этой фигуре. В других произведениях Гоголя (после «Вечеров...») везде присутствует крах, во всех повестях, в романе-поэме, комедиях, в «Коляске», в «Портрете», «Записки сумасшедшего», «Шинели» ..., да и сам «Ревизор» - крах позорный. Я думаю, что и Подколесин тоже голос автора. И Хлестаков, и Чичиков. «Чичиков» от слова «чичига», то есть чёрт, тоже не последний персонаж Гоголя. Он тоже его внутренний враг (и чем-то, отнюдь не внешне, похож на самого автора), с которым он сражался и в жизни, и в творчестве, а раз это его внутренний враг, то уж он-то в первую очередь должен был потерпеть поражение. Если Гоголь о себе говорит, что он знаком со «страстями-лицемерами», то он не отделяет себя от «безобразного города», который есть не кто-то другой, это он сам, автор этого города, это его собственная душа (и всякого из нас, конечно). Получается, что личный момент авторства (Агафья Тихоновна) лишь один обертон, важный, конечно. Но автор - весь «город», многоголосый, многоликий, множество. Мы сами по себе есть как бы зажатое в себе множество векторов, не скажу «сил», скорее, персонажей. Персонажи - авторы своего автора.

Но не всегда так бывает. Все равно, даже после весело-радостного, и тем более после такового, звучат слова: «Скучно оставленному. И тяжело и грустно становится сердцу, и нечем помочь ему». И лучше бы ему остаться персонажем на сцене, танцующим гопак, - да не вытанцовывается! Метафизическая тоска не гасится самоиронией. 


\section{$* * * * * * * * *$}

Подобно тому, как в философии, чтобы понять центральные точки поворота, нельзя обойти Платона с Аристотелем, Канта с Гегелем, чтобы понять историю русской ментальности недавнего времени, и значит, современности, невозможно обойти «триаду» авторов: Пушкин, Гоголь, Достоевский. Но с точки зрения языка, языка как покрывала души, надо назвать триаду Гоголь, Достоевский, А. Платонов. Почему же не Л. Н. Толстой? И многие, многие другие? Потому что нас интересует судьба Души, какие перепады в этой судьбе рождают автора, какие в ней завязываются узелки, развязать которые призвано творчество. История Души не читаема, ее напор если не разрывает плоть и непрерывность языка повествования, то сильно напрягает все формы его. Трудно себе представить, чтобы сила гения, звучащего в произведениях каждого автора из этой триады, была бы результатом просто работы какой-нибудь стилизации. Нет, там Душа жаждет бежать из своей темница, и потому речам ее «без волненья внимать невозможно».

Эта узловая линия истории русской души двойственно определена: и личной историей жизни, и метафизически, тем, что авторы нашей «триады» так неуловимо со своей неповторимой и едва уловимой музыкой, смеясь и плача (даже рыдая, как Ф. М. Достоевский), указывают нам на Небо и Землю одновременно.

Язык у наших авторов как будто неправильный, как если бы его нечто невыразимое и нечитаемое распирало, разрывало. Переводчик (Abdul-Hâdi, 1911) небольшого текста Ибн Араби («Трактат о Единстве») утверждает, что арабский язык «алгебраичен». Поэтому, если рассуждение правильное, то на арабском невозможно сделать синтаксическую или лексическую ошибку. Грамматика не позволит. Он также утверждает, что китайский и малайский языки в этом схожи с арабским (соблюдение грамматических правил не позволяет делать ошибки в рассуждении и наоборот, правильное рассуждение не допустит грамматической ошибки). Русский язык совсем не алгебраичен. Он топологичен. Он очень нюансирован, каждый очередной нюанс меняет направление размышления. А греческий - это линейная геометрия. Латынь
- это аналог тригонометрии. Так мне представляется. Современный французский - это вообще арифметика. Abdul-Hâdi на основании алгебраичности арабского языка утверждал, что этот язык имеет божественное происхождение [3]. Русский же язык, если его не по формальным и классификационным правилам рассматривать, обладает большей смысловой плотностью или емкостью, но и он разрывается, когда гений желает высказать нечитаемое, несказанное, то, что нам надо знать, но недоступно для любой технической передачи, а только от сердца к сердцу. Причем от и к сердцу боли.

Я бы добавила к первой двойной «триаде» еще одну: Чайковского, Мусоргского и Стравинского. Русскую культуру современности (то есть двух с небольшим последних веков) нельзя себе представить без музыки. Картина была бы слишком односторонней и совершенно неверной. Не развивая далее мысль о русской культуре, скажу только, что общим автором ее является сам язык, он создает и играет, открывая множество небывалых возможностей для переживания, выражения разнообразных нюансов жизни Души; литература и музыка здесь больше, чем философия и наука. И музыка тоже созвучна языку, только не на уровне интонации, приемов или стилей. Она родственна языку в нашей культуре не тому, что русский язык говорит словарно, а тому, что за словарем утаивается, не поддается переводу. Поэтому невозможно переводить ни Гоголя, ни Достоевского, ни Платонова. Поддается переводу только словарь, а напряжение Души в нем уже не прочитывается. Музыка более универсальна, поэтому русская музыка широко известна и исполняется, но не всегда при этом понимается.

Moе рассуждение может показаться слишком запутанным, а выводы слишком простыми, автор ведь должен быть один, авто - значит «само», он самодеятелен, а у меня получилось, что это неопределенное множество персонажей, проецирующих в частное (или даже случайное) имя свое призрачное чаяние о себе самих как реально действующих, чтобы зрители признали их реальными, во плоти, самими собою, а не только действующими в плоскости представления, тенями сна. Подобно тому, как реальные зрители на концерте какой-нибудь «звезды» проецируют себя в точку на 
сцене, где эта «звезда» издает звуки, все вместе отдают свою страсть быть, создавая некие единый энергетический центр, их же и вдохновляющий. Зрители, частичные существа, вожделеют о своем Едином, о своей полноте, о своей плоти как истинной своей субстанции. Вне призрачного единства концертного зала они суть осколки, блуждающие частицы; собираясь в одном поляризованном каким-либо способом информационном энергетическом поле, определенном и качеством (уровнем) этих частиц и еще многими-многими параметрами, они создают энергию массы вокруг «звезды». Но «звезда» тоже не есть автор, как не авторы и частички массы. В слиянии в одно целое зала, в этой «плероме», автор не присутствует, и его отсутствие есть пародия на отсутствующего в творении творца. Концерт окончен - зритель возвращается вновь к своему существованию, лишенному сверкания и значимого содержания. Он лишается субстанции, она снова вне него. «Тот путь без дороги..... зовущий в блистающий мир», как звучат отрывочно слова песни Двойной Звезды у А.Грина. Блистающий мир для частичек недосягаем.

Таков универсальный посредник - автор в произведении, звезда на сцене, харизматическая личность на экране телевизора, политик, любой публичный деятель. Любой такой персонаж в публичном пространстве - фокус вожделений публики (даже когда публика развлекается от скуки), публики, которая есть разрозненная множественность. Разрозненная всегда, даже в самых сплоченных и традиционных группах, просто каждый персонаж, жаждущий самого себя как полноты и самости, включил этот фокус, центр, средоточие в свою психическую конструкцию. Он в каждой ситуации представления и включенности в этот процесс грезит о своей божественности, о себе как источнике реальной самодеятельности.

Но как можно мечтать о свободной воле (самодеятельность = свободная воля), если ты вообще не свободен? Публика (персонажи) мечтает о себе как о высшем САMO, но в то же самое время хочет остаться многоцветной, пестро-множественной, войти в Царство Небесное, так сказать, с черного хода.

Себя самого как себя самого знает только Бог [10,56]. А мы забыли, кто мы есть, по словам Боэция. Припоминание, о котором говорит Платон, тогда означает «вспом- нить себя» прекрасными, богами. Ведь люди суть смертные боги, а боги - бессмертные люди (Гераклит). Тот, кто берет на себя роль автора, находится в состоянии припоминания себя, иногда напоминающем тягостные усилия проснуться, очнуться от ночного кошмарного сна, преодолеть вязкость фактичности.

Мы сейчас не говорим о традиционной культуре, где не конкретное человеческое существо было автором, а, говоря, разумеется, крайне обобщенно, Воля Бога, Воля Неба, Провидение, Карма и пр. Высший принцип. Авторство есть проблема именно современной культуры. Искусство же, для которого авторство особенно значимо, сейчас ничего общего не имеет с тем, что, как мы думаем, было искусством в традиции, как современное образование не есть обучение и посвящение традиции. Искусство в современном понимании этого слова предполагает своим автором конкретного человека с вполне определенной биографией и именем. Цель его - свидетельство жизни конкретного человека, условий его существования, крах этого существования и протест против его конечности. Авторы и актеры смертны, а персонажи - бессмертны. Раз они созданы, то переживают своих творцов. Творец умирает и даже забывается. А персонажи не замечают его ухода, продолжают жить, творят из своих творцов легенды, создают им судьбу и историю. Настоящим автором, - если это не пустота подражательности, - оказывается синтезирующий в себе голоса возможных персонажей и сам являющийся персонажем своего произведения человек, потерпевший крах. Крах терпит современный человек, поскольку он претендует на авторство собственной судьбы. По слову К. Ясперса, это крах экзистенции, не только пережившей некую трагедию, но именно крах экзистенции, предстоящей перед трансцендентным, беззащитной перед ним. Человек, потерпевший крах, не может прибегнуть к защитам, предоставляемым бытующей в данном месте и времени культуры. Он обнажен перед неведомым, и сам может этого не знать ӥ[9].

С одной стороны, творчество - это защита, а также и изживание сердечных ран, как прекрасно говорилось прежде (личностный момент творчества), а с другой - это любовь, которая есть познание не эмпирическое и, уж конечно, не научное и рациональное, не фактического мира, а прямо-таки лжена- 
учное и антирациональное, познание, продвигающее нас во мрак неведомого, это познание сверхзнания. Если некто творит ради культуры, создает культурный предмет, то он не обязательно будет автором. Наше «само»в акте творчества возвышается до САМО-неведомого в этом векторе во мрак, тёмную тайну, отнюдь не падая при этом в подсознание. Подсознания, как и любой «ад», создается нашей мыслью и нашими чувствами, соизволяется нами и обретает действенность против нас самих за счет нашей же собственной энергии. Речь, конечно же, не идет о фантастике любого сорта. Скорее наоборот, хотя самое фантастичное может со временем оказаться реальностью, но оно всегда недостаточно подлинно и слишком фактично.

Итак, автор жаждет реальности, а не фактичности. Как говорит Гамлет своей матери, королеве Гертруде: «Я не хочу, того, что кажется. Я хочу того, что есть». Он в этомавтор. Автор событий и автор текста о событиях. В каком же смысле? Здесь персонаж есть автор, а автор - наблюдатель, и разгадка в центре пьесы - театр в театре, мышеловка. Пьеса держит внимание не только своим действием (драма и есть действие), но голографическим устройством. Вообще, то, что можно назвать бесконечным смыслом подлинного произведения искусства строится по принципу голографии, чаще всего в строении произведения заложен более важный смысл, нежели в самом внешнем тексте. Обычно текст интерпретируется, а построение - анализируется. Можно делать и наоборот.

Мы забыли, кто мы есть, припоминанию служит чаще построение, ведь оно должно быть в обход прямому осознанию. Точно. Как в обыденной жизни: пока силишься что-то вспомнить - не вспоминается, стоит отвлечься - забытое тут как тут. Хочу разъяснить свою мысль на примере французского фильма «Вспомнить прекрасное». Выбираю этот фильм, в том числе и потому, что он не вывернут наизнанку интерпретациями; этим мы и займемся. События происходят в психиатрической лечебнице. На внешнем уровне - сентиментальная история о любви двух душевнобольных людей. Однако фильм построен с легким налетом иронии, не насмешки, что всегда грубо и недостойно, а только нюансом, едва уловимым. И не над персонажами или пороками.
Ирония имеет право быть (в силу того, что в ней всегда присутствует осуждение) только по отношению к самим себе, к нашему восприятию мира. В этом смысле она здесь относится скорее всего к нашему излишне серьезному восприятию мира, к болезни как «делу», к погружению в нее. Ведь болезнь это тот же враг, что был и у Гоголя, противник жизни в нас самих нами же производимый, и взращиваемый, и сражающийся против нас. Это наша анти любовь к самим себе.

Надо заметить, что поводом обращения к этому фильму для меня был никем не замечаемый, а для меня явный второй смысл, скрытый в построении произведения как «прекрасного». В конце фильма, точнее, в конце маленького любовного романа, выздоровевший герой (любовь ведь исцеляет) находит, наконец, свою возлюбленную, потерявшуюся в городке, стоящую посреди улицы, окончательно погрузившуюся в болезнь (между прочим, болезнь Альцгеймера, в западном мире весьма распространенную, совсем не свойственную, например, индусам). Героиня, несмотря на болезнь весьма красивая, неверным жестом поднимает одну руку к небу, жест отдаленно напоминает полет птички. Он от жалости, любви и сострадания припадает на колено и приникает к ней. Группа очень напоминает монумент «Минин и Пожарский» в Москве, на Красной площади. Невозможно не узнать, если отстраненно смотреть на сюжет, не буквально его воспринимать. Это ключик для разгадки всего латентного смысла. Эти «Минин и Пожарский» символически собою представляют поддержку Неба и Земли (здесь она - «Пожарский», указывающий неверною рукою на Небо, а он - «Минин», ближе к земле, ну, просто как Будда, прикасающийся к Земле с просьбой о даровании силы). Да, конечно, речь идет о любви, болезни и здоровье. Но только ли? Если вспомнить все с самого начала фильма, то явно, что это танец двойственности. Двойственность - принцип проявленного мира. В начале фильма в клинику приезжают две сестры - одна здоровая, другая больная. Остается, естественно, больная. В конце фильма герой выздоравливает, героиня погибает. В жизни остается здоровый. В решающим момент врач (врачи клиники несколько - весьма отдаленно, но все же, - напоминают небожителей) по- 
казывает сверху, с верхнего этажа клиники (с Неба) другого недавно прибывшего больного, как бы прошлое нашего героя, сидящего на стуле в позе совершенно раздавленного, бесчувственного существа. И врач говорит герою, находящемуся в отчаянии, в пограничной ситуации, готовому снова впасть в болезнь: ты хочешь снова быть таким? Здесь развилка между здоровьем, для которого нужно волевое усилие, и болезнью, которой, как потоку, невозможно сопротивляться, если не найти точку поворота. Начало фильма созвучно с финалом там развилка и здесь тоже; в центре сюжета - «Минин и Пожарский», в этой скульптурной группе один указывает на небо, другой на землю. Правда, есть еще один смысловой центр: когда героиня смотрит в зеркало, в котором видит свое страшное и старое лицо, свое будущее, или же это прошлое? Это лицо ее матери, умершей от этой ужасной болезни. Это и прошлое и будущее в одном отражении. В сцене выбора врач указывает на землю, будучи на верхнем этаже здания (на Небе). В фильме множество таких раздвоений, как множественное отражение одного и того же в анфиладе зеркал. Пути расходятся, но эти узелки волевого усилия без насилия более значимы, чем все «пути» (и с заглавной, и с прописной). Остановись, замри на мгновение, и увидишь «Тот путь без дороги..... зовущий в блистающий мир».

Понятно, что мы могли бы вычитать в этом произведении и множество других смыслов, на то оно и произведение искусства. Хорошее произведение, как правило, устроено голографически, все дело в том, насколько это устроение музыкально (конечно, не в смысле присутствия там музыки), чем тактичнее эта музыкальность (прекрасное, которое надо вспомнить), тем произведение более совершенно. Внутренняя музыкальность без всяких ухищрений создает прекрасное произведение. Тем более, что кино французское, американское дало бы однозначный и простой, как рекламный ролик, смысл, легко прочитываемый. Страшно, значит страшно; смешно, значит смешно, трогательно, значит трогательно и только. Эмоции могут чередоваться, но не более того. Американские фильмы читаются в одну строку. Чтобы читать более сложное кино, надо включить способность не только видеть, но и мыслить панорамно, или так, как мыслит дирижер орке- стра, перед которым партитура из множества разных строк (партий). В фильме же «Вспомнить прекрасное», который мы взяли в качестве иллюстрации, даже название многозначно. Вспомнить прекрасное созерцаемое (произведение, природу), прекрасный момент жизни (есть и такие эпизоды), а может быть, вспомнить себя прекрасным, прекрасной. Это и есть эпизод, когда внешне еще красивая героиня смотрит в зеркало. В этом эпизоде тоже есть развилка, два пути - один в прошлое, в родовую память, сулящую ей дурную будущность, или другой, возвращающий к себе прекрасной, заглядывающей в зеркало. Но трудно вспомнить себя изначального, так сказать, как в первый день творения, вернуться к началу, или хотя бы на несколько лет назад. Может быть, это намек на платоновское припоминание? Всё вместе. Ведь на самом деле прекрасное произведение не читаемо, самое ценное в нем не считывается.

Мы только отражения, рисунки на стекле, отражения в зеркале, тени в сумерках, бегущие друг за другом, жаждущие друг друга убить, или любить, укусить или приласкать. Но разве тень способна на какоелибо самодвижение? Она - персонаж, автор в другом месте. Но если автор сам есть сумма его персонажей, руководящих им и творящих его, то кто же автор? Толстой зеркало русской революции, как если бы зеркало порождало своих персонажей. Действительно, странный предмет - зеркало, без своих отражений оно не есть оно само, но оно их не производит и не порождает.

\section{$* * * * * * * * *$}

Так и автор - он всё и все вместе, он и зеркало, ничего не порождающее, он и все отпечатки в этом зеркале. Он и сам только отпечаток, представленный на сцене, в публичном пространстве. Имя его - только опознавательный значок той сцены, на коей он выставляется. Сцена есть публичное пространство. Как сейчас говорят, если ты не в сетях, то тебя и вовсе нет, шире - если ты не в публичном пространстве, то ты не существуешь. Что это за существование, каков его принцип? Видимость свободы здесь возникает за счет того, что человек вступает в публичное пространство только в качестве маски (как говорилось на Руси, «хари», личины, прошу прощения за грубое звучание 
для современного слуха). Автор здесь тоже актер и персонаж. Публичное пространство - это маскарад со своими страстями, смертями и отравлениями. Маски есть отпечаток ожиданий таких же участников этого пространства, мест, ячеек, можно сказать. Маски создают устойчивый, а, стало быть, более реальный образ, чем изменчивая природа актеров. Амплуа актера есть его жизненное пространство. Свобода здесь создается за счет отрешения от сущности, именно здесь человек есть самость, лишенная сущности, по меткому выражению Гегеля в «Феноменологии духа», (в русском переводе 1911г.). Сущность остается как нечто "внутреннее» по отношению к общению через посредство знаков-феноменов.

Феномен плюс знак = факт, в сущности нет никакой фактичности. Где ставится центр человеческого существа - в фактичности или в сущности - в этом водораздел, или скорее, поворот от традиции к современной феноменологичности. Факт мы воспринимаем как нечто определенное, ставшее стабильным, помещенное в прошлое или в вечный порядок, и то, и другое мыслится нами как нечто точно определенное, хотя нам и не известное полностью, но известное частично. Физический факт, исторический факт или факт любой другой научной дисциплины более или менее законен, так как это абстракция, он законен только внутри той или иной познавательной схемы. Факт как реалия - вещь незаконная для понимания мира и знания о себе. Реальность не сложена из фактов или, как красиво сказал Ортега-и-Гассет, реальность не делится на разум без остатка; если она непрерывна, то ее невозможно сложить из фактов. Но знание может быть не фактичным. Философия, отказавшись от любых размышлений о сущности, даже от самого имени сущности, погрузилась в , в феноменологичность, фактичность и публичность (современный философ таковым является не для себя, а зависит от признания его заслуг читающей публикой). Поэтому и ее доминирующим стилем стало развертывание и рассматривание деталей, мелочей, даже в том случае, когда казалось бы рассуждают о метафизических реалиях. Рассуждают, как старьевщики рассматривают и оценивают свой «товар». Да что и остается делать детям постмодернизма? Они существуют на свалке и вынуждены становиться свалкой.
Выйдя на рынок (публичное пространство сегодня - это рынок информации, идей, страстей и прочих информационных образований, в значительной мере химерических), философия теряет «серебряную нить», соединяющую ее с метафизикой Традиции (в смысле Р. Генона). Понятно, что феноменологичность, фактичность, публичность (могу добавить еще многое) не есть одно и то же, но это бросающиеся в глаза отличительные признаки современной ментальности.

Практика есть абстракция. Опыт есть абстракция. Факт есть абстракция тем более. И даже физический факт. Исторический факт, самом собою, формируется на фоне согласия относительно того, что имеет значение, а что не имеет такового, в него входят определения события, места, времени, лиц и многие другие определения, все сложившиеся с разной степенью условности. Вся информация, сжавшаяся до факта, поляризована доминирующими в данном социуме ценностями. В этом смысле нет объективно существующих фактов истории, поскольку история сама существует только как рассказ об этих фактах истории. Существование фактов истории аналогично существованию на сцене персонажей, ищущих своего автора.

В физическом факте условности не меньше, кроме «договорных» есть еще великая доля неопределенности, подобная той, которая выявилась в физике в понятиях «темной материи и темной энергии». За каждым фактом стоит множество привходящих не обнаруженных и не обнаруживаемых условий. Они не могут быть обнаружены отчасти из-за временной ограниченности знаний, из-за сужающих горизонт познания исходных исследовательских позиций (исследование как преследование предполагаемого знания по определению ограничено, следовательно, не совсем есть знание), а отчасти и по природе. То есть под поверхностью фактичности колышется океан неведомого и не выявляемого, от которого покрывало фактов отнюдь ничем не отделено.

Факт - иллюзия в самом тяжелом смысле слова, ведь он себя выдает за истину, упорно и неопровержимо. Его можно опровергнуть только другим фактом, а тот еще другим и так до бесконечности. Поэтому наука стремится, как мы думаем, к истине, никогда ее не достигая. И в отчаянии даже 
заявляет, что не к истине как таковой, а к договорной истине.

Публичное пространство в социуме аналогично физическому миру как фактичности. Если социум есть общение, и если общение мы уподобим поверхности зеркала (ведь в общении нет субстанции, оно подобно взаимодействию теней, отражений, взаимодействию образов на поверхности зеркала), то публичное пространство есть поверхность другого зеркала, отраженного внутри первого, это тени от теней и их бесконечное умножение. Энергетические воздействия мы пока оставим с стороне, хотя это очень важная сторона общения. Это театр в театре, мышеловка. Актер сам для себя и зритель, он себе публика, смотрит на себя со стороны, он должен выглядеть, так и лицо в публичном пространстве должно выглядеть определенным образом. Есть такие персоны, которые всегда смотрят на себя со стороны, и при этом настолько отработали принятый ими и ожидаемый другими образ, что выглядят искренними и естественными, как если бы человек оставался наедине с самим собой. Когда актер забывает о публике. Это уже, как говорится, высший пилотаж.

И, наконец, театр есть представление, его автор - муза; он противоположен философии, которая есть самодеятельная и самостоятельная мысль, ее автор - сама богиня Афина, истина Вселенной. Существует изображение Афины, которая держит в правой руке загадочный диск. Это явно не оружие. Диск имеет в центре массивную выпуклую сердцевину. Такой диск не может лететь, как летит оружие индусов, чакра, тоже диск, несколько, почти незаметно искривленный, полый в середине, скорее даже тонкий обруч. Не похожи на предмет в руках Афины и другие виды оружия. Здесь есть аналогия с «шишкой» в руках Асклепия, которая, конечно, не есть ни яйцо, ни шишка, ни чаша. Есть расшифровка этого предмета как шишковидной железы, эпифиза; она маленькая, но от нее зависит жизнь и здоровье человека. Она есть «корень» человеческого существа, подобный «глазу древа», который у реального дерева находится между двумя средами, воздухом и землей. Эпифиз находится, как «глаз древа, посаженного Небом», тоже между двумя средами - тонким и физическим мирами. Через него человек укоренен в тонком мире. Предмет в руке Афины, которая есть сестра Аполлона, покровителя врачебного искусства и отца Асклепия, тоже не есть некий бытовой предмет. Это модель нашей галактики, а может быть и Вселенной.

\section{$* * * * * * * * *$}

Errare humanum est.

Человек есть «перевернутое вверх корнями дерево» (Платон), человек есть растение, посаженное Небом (кстати, и наука может свидетельствовать об этом. Ведь первые клетки, возникающие после зачатия человека, это клетки «глаза», то есть мозга, и кишечника. Вначале человек (тело) есть глаз с хвостом. Все это не наука, антинаука, псевдо, квази, ересь, наконец). Только рожденный Небом вернется на Небо. Мистика, религия, Ну, вот и хорошо. Мир не во зле лежит, нет, он просто содержит в себе внутреннее сомнение, он сомнителен, ложен поэтому. Так утверждали древние йоги. И я так думаю. Поэтому в этом мире успешен тот, кто по его закону и действует, включая и тех, кто «не от мира». Если ты по его законам живешь, то и живешь правильно в нем, то есть ты истинен, если ты сомнителен; ты истинен, если ты «во зле» и в согласии с этим, то ты добр. Как можно было бы стремиться к истине, если бы мир не был бы покрыт ложью? Стремятся ведь к тому, что отсутствует, чего не хватает. Следовательно, в таком мире правда - это ложь, а ложь - это «истина». Это, понятно, не мое открытие. Тогда нас, куда не кинь взгляд, везде подстерегает парадокс лжеца. Выход же все равно есть, это - игра, то есть не ложь и не истина, не реальность, но и не подделка, не иллюзия в буквальном смысле слова. Игра есть состояние «между», она - посредник. Между чем и чем? Она законным образом, если ей не злоупотреблять, есть универсальный посредник, как деньги, в которых есть момент игры, но уж очень сильно подверженный злоупотреблению. Деньги - посредник между миром мертвых и живых, и есть, собственно говоря, мертвое время, которое никогда не переходит в живое. В мир мертвых движение одностороннее. Оттуда никто и ничто не возвращается, дверь открывается только с этой стороны и только в ту сторону. Так и в мире игры, если в него попадаешь, то выход из нее только в упорную иллюзию. Театр - это 
игра по самой своей природе. Театральное представление есть тоже посредник. И тоже между миром живых и мертвых. Первично ведь театр - это мистерия, посредничество с миром богов, теней, предков. Рампа - не пересекаемая граница, как граница между миром живых и потусторонним. Автор потустороннего мира - явно не мы с вами, но он выставляет на сцену тени из своего мира. В этом смысле современный театр есть чистая профанация. Нам показывают какие-то факты жизни, чем не занимался традиционный театр, сохранявший в себе еще дух мистерии.

Наш ускользающий от определения «автор» не совсем игрок (игрок производит только иллюзию, мир как сон), ведь он стремится к реальности. Отличается он и от человека практики, включая как техническую материальную, так и технику психологическую и практику, имеющую некую духовную цель. Человек практики не может быть автором, потому что он ставит себе цель. Наш автор не ставит цель «создать произведение», получить результат. Его цель не есть его частная цель, но она и не просто некое место в публичном пространстве. У нашего автора есть невидимый водитель; именно его цели он преследует. Чайковский плакал над судьбой Германа, музыка ему была слышна «объективно», он ее записывал. Но он не был медиумом в оккультном смысле. Гений укоренен в неведомой для нас области Неба, которого голос он и есть. Поэтому верно определение гения, данное Кантом (видимо, он и сам знал, в чем тут дело!), отличающее гения от таланта. Талант в совершенстве следует правилам вкуса, гений сам порождает правила вкуса, то есть в нем самом есть исходная точка творения, он законодатель, но законодатель для искусства, для культуры и только. Он тень творца, дающего закон природе.

Интересно, что есть странные авторы, которые, как кажется, имеют источник творчества как будто черпают энергию, образы, слова и музыку из неведомого; точку опоры имеют вне себя. Но этот источник в опосредующем мире, в том, что сейчас называют тонким миром. Как утверждают некоторые ученые, изучающие необычные проявления человеческой психики, мир этот наполнен так называемыми психическими остатками погибших насильственной смертью людей. Тогда этот гений, этот психический остаток погибшего человека, не способный обрести вечный покой, становится тем, что называется «злым гением». Хорошо, что наш мир, воспринимаемый только «обычными» чувствами, отделен от тонкого мира дверью, открывающейся только в одну сторону. Наши чувства при нормальном состоянии нашей психики туда не проникают.

А перед этой дверью находится театр. Не тот или иной в ту или иную эпоху, в той или иной культуре. Театр как явление и принцип, как представление и как игра. С самого начала необходимо отвести предубеждение относительно противоположения Аполлона и Диониса. Оно было ярко высказано Ницше в самом начале его творческого пути, и яркостью загипнотизировало всех впечатлительных. Для него эти фигуры были скорее символами психической жизни, чем метафизическими принципами. Если же к «богам» древности относиться как концентрированным смыслам, свернувшимся в образ, как бы в фигуру речи, то они не столь определенно противостоят друг другу.. Вспомним, однако, что Афина спасла сердце Диониса после того, как он был разорван на части. Афина - сестра родная Аполлона, даже более Аполлон, чем сам Аполлон, не такой уж однозначный бог. Афина - богиня истины, а мы знаем, что Дионисом тое открывается истина, не случайно диалоги Платона, - а он был посвященным, куда уж более! - происходят на пирушке в честь Диониса, с возлияниями, конечно же. И в честь Афины. Например, «Парменид» разыгрывается после панафиней, главного праздника, точнее, мистерии Афин, города, в котором истина и доблесть суть смысл жизни. На пирушках были и представления, Философия и театр были рядом. Но собственно театр - это продолжение мистерии, соревнования между поэтами, длящиеся неделю. Как утверждают, поначалу это была представленная перед зрителями мифология, здесь зрители уже не участники самой мистерии, а представление уже не собственно ритуал. В этом представлении есть определенная свобода, в уста мифологических персонажей вкладываются мысли и чувства современников наряду с вечными истинами. Понятно, что мистерия, ритуал и сам миф суть вечные истины, неизменные, независимые от интерпретации. Мистерия не есть тайна и загадка по своей сути, ритуал не есть просто застывшая форма дей- 
ствия, а миф не есть сказка и выдумка. Bсе это единый отпечаток высшего смысла бытия, раскрытый для посвященных. А как же быть не посвященным? Они переживают, чувствуют, приходят в состояние очищения страстей. То есть готовят себя к посвящению тоже. Удается избранным. То же самое философия, еще у Пифагора она была предваряющей ступенью посвящения, потому она не знание истины, а только лишь стремление. Философы по призванию уже суть избранные. Те же, кто хочет достичь с помощью философии какие-то другие цели, посторонние этому движению к истине, думают, что можно войти в Царство Небесное с черного хода.

Философия и театр разошлись, что интересно, в одно и то же время на Западе, и на Востоке (в то время запад был еще Востоком). В Греции появилась трагедия и сатирова драма, которые дополняют друг друга. В Индии возник театр как публичный ритуал, натья.

Ошибка сознания - придавать субстантивность тому, что только феноменально $[10,56]$. Это верно, но все ли феноменальное действительно феноменально, не тянет ли за собой явление (феномен) неявленное, загадочные 95\% темной «материи-энергии», то есть невесть что. Пойди туда, не знаю куда, принеси те, не знаю что. Каждый феномен нас именно туда и отсылает, наряду с другими адресами, другими феноменами. Скользит по поверхности времени, но как-то неправильно скользит, непредсказуемо. Плетение судеб - это катящийся клубок связей феноменов между собой и с невесть чем еще, поэтому символ из детской сказки относительно яблочка на блюдечке с голубой каёмочкой (каёмочка на первый взгляд есть небо, но возможно, что и бездонный космос, блюдечко - феноменальный мир, а яблочко - клубок судеб нашего «я». На каждом отрезке наше «я» отличает себя от других соседних ниточек, но оно есть просто отрезок всей бесконечной нити. «Невежество» - это неспособность отличить САМО от тела и сознания. [10,56]. Гермес Трисмегист говорит: «Грех души в незнании, познание есть ее добродетель» $[10,57]$.

Aesthesis (мы ведь его считаем началом искусства и даже отчасти всей культуры), однако, не есть по сути познание, это - дискриминирующее сознание (хорошо-плохо, добро-зло и т.п.). а само сознание есть вид невежества, оно гаснет вместе с жизнью. Ни порок, ни добродетель не пересекают Моста бессмертия (Упанишады, то же утверждает и Мастер Эккхарт: в Царство Божие никогда не войдет ни порок, ни добродетель). Победа над Драконом (Веды) и победа над Марой Будды суть аналоги, причем и там и здесь в этой битве боги оставляют героя один на один с врагом, исчезают. Это означает победу САМО. Поворот в судьбе своей и судьбе мира возможен только при опоре на САМО. И это поворот к знанию. Мы забыли, кто мы есть, вспомнить - вернуться к себе как самому СЕБЕ [10]. Яснее сказать невозможно. Этот поворот ускользает от феноменального, он не присутствует в фактичности, он не есть факт, но печать истины на поверхности фактичности. Множество предшествующих рождений Будды есть свидетельство того, что многое становится единым даже будучи развернутым во времени, то есть это временной аспект соединения, но есть еще множество других множеств, и все они сливаются в одном Едином [10].

Факты науки есть как бы посредники между теорией и ускользающей беспрерывно меняющейся непрерывностью данных нашему сознанию, но еще не схваченных им, то есть данных, но еще не взятых. Методологи на этом акцентируют свою мысль. Эти не проясняемые по смыслу данные схвачены в понятия теорией. И далее происходит их взаимная игра в объяснения. Философия наследует из своего недавнего прошлого скептическое отношение к метафизике, выделяет фактичность в противовес метафизике, понимая последнюю как тоже игру, но пустую, в абстракции, схемы и принципы. При этом остается не ясно, чем отличаются факты физической реальности, психической и тем, что же есть на самом деле (как всегда интересуется наивное сознание, устами коего говорит истина, внимать которой мы не в состоянии). На страницах романов полно фактов, при этом не фактов сознания персонажей, а фактов того, что называется художественной действительностью, творимой якобы воображением. В таком случае проблема просто вытесняется в другое неопределенное, реальность которого есть реальность слова. Факт-слово-вещь все втроем становятся нереальными. То есть либо мы само вообра- 
жение - как репродуктивное, так и продуктивное одинаково, - считаем материализующей силой, создающей материю факта и вещи, либо, что близко к этому, мы его считаем формообразующей силой, которой поддается некая неопределенная материя, не имеющая бытия как таковая, меон, $\mu \eta \dot{~}$ $\omega v$. Что такое факт «на самом деле» и есть ли он на этом самом деле, остается непонятным. Физический факт по самой своей идее предполагает субстанцию, в которой он выступает как вещь, то есть отделяется от окружения. Если его нельзя отделить, то его и нет. Это особенно хорошо видно в эксперименте, когда место, где получают факты, лаборатория, очерчено магическим кругом, не позволяющим неконтролируемым влияниям попадать внутрь лаборатории, причем не зависимо от того, мысленный это эксперимент или реализуемый практически. Факты здесь всегда условны. Ведь на самом деле контролировать человек может только маленькую площадку окрест себя, да и то в малой степени. Если в «факте» сохраняется определенная мера условности (зависимости от теории, от наших понятий и представлений, от степени контроля за границами наблюдения), то это хотя и факт, но не свидетель истины. Он тогда ничем не отличается от фактов литературного произведения в глазах его персонажей. Под ним нет никакой субстанции, кроме слов. А слова существуют не только для того чтобы истину открывать, но и для того, чтобы ее скрывать. Потому верить фактам, - это все равно, что верить сплетням. Самые изощренные сплетни - это художественные произведения, вот им и надо верить, хотя бы отчасти, на какое-то время становясь персонажами, изобретающими эти факты, и проецирующими во вне произведения своего автора в качестве субстанции своей возможной фактичности.

Человек видит такое положение дел, такую фактичность, такую фактуру и делает далеко идущие выводы, предлагает быстрые решения. Однако между фактом и действием нет непосредственной связи. Действие может оказаться в любом направлении. Или не быть вообще никакого. Из этого зазора рождаются вообще познание и, в особенности, абстрагирование, но отсюда же и короткие мысли и быстрые решения. Но не обязательно короткие мысли есть признак низкого человека, у такого человека могут быть весьма изощренное мышление, проницательность зла. Этот разрыв должен как-то дойти до связки «фактичность - решение». «Клубки мысли» катятся как яблочки на блюдечке из сказки, яблочко, которое открывает Ивану-Дураку всякое знание. Каждому Ивану по яблочку и блюдечку, таково мое пожелание всем, и нам в том числе. Потому что это сотрет всякую несуразность, все станут из иванов-Дураков иванами-Царевичами в один момент И мы все будем счастливы и навеки. И здоровы. Итак, с фактами мы покончили, вернемся к нашим авторам. И самый острый случай в истории авторства перед нами. Это легенды об авторстве шекспировских произведений: был ли фактически живший Уильям Шекспир действительным автором своих пьес? Вот в чем вопрос.

Шекспир настолько фантастически многогранен, гениален, что различные версии об авторстве совершенно естественны. Трудно подобрать подходящего персонажа из известных исторических личностей на эту роль. За рампой, любой чертой, отделяющий представление от присутствующего на представлении зрителя и слушателя, участвующего только в качестве внешнего свидетеля происходящего на сцене, есть иной мир. Исходно это мир богов, мир предков, мир теней, в любом случае на сцене не живые существа. Поскольку актеры лишены собственной сущности, они водимы по сцене и по тексту. Но автор тоже заключен в этом мире теней. Он только на сцене отсутствует как автор, это значимое отсутствие, наподобие центра, оси колеса, отсутствующей на поверхности обода, на окружности.

Что за загадка! И разгадка тоже в центре - в мышеловке, в театре в театре. Для того спектакля, который актеры будут представлять перед королем и королевой, казалось бы, есть автор - это Гамлет, актеры - это его друзья. Он дает главную тему и смыл представления, актеры воплощают замысел. Но на самом-то деле пьеса, разыгрываемая внутри спектакля, есть улика, по которой можно восстановить и авторство объемлющей пьесы, то есть самого «Гамлета». Конечно, этим автором не может быть ни лорд, ни философ; это человек театра. Театр забирает всего человека, нельзя быть одновременно человеком сцены и зрителем. Сцена - это потусторонни 
мир, мир теней, призраков, богов и бесов, там только «духи», облаченные в одеяния людей, если зрители это человеко-духи (как Ремизов перевернул слово Р. Штайнера «духо-человеки»), то на сцене это просто духи в оболочке человека. Оболочка нужна, чтобы было понятно для зрителей. Рампа обязательна, или черта, занавес, круг, что-нибудь запрещающее проникать чужим на сцену. Итак, автор-Шекспир есть театральный человек. Он не может быть кем-то еще, конечно, у него есть частная жизнь, но не другая роль в публичном пространстве. Он поглощен сценой. А если посмотреть шире, то этот автор и есть сама мышеловка. Это вся группа актеров. Разумеется, есть ведущий и ведомые, но это сути дела не меняет. А кто в «мышеловке» автор? В этой сцене интересно то, что бродячая труппа актеров фактически импровизирует пьесу на заданную тему.

Автор Предисловия к Собранию сочинений в двух томах У.Шекспира (на русском и английском языках) [8] резюмирует вопрос об авторстве: «Шекспировская тайна, безусловно, существует, но это не биографическая загадка, а тайна гения, которому сопутствует то, что поэт-романтик Джон Китс назовет "негативной способностью" Шекспира, его поэтическим зрением - видеть все и ничем не обнаруживать своего присутствия. Уникальная шекспировская тайна, которая принадлежит личности и времени, когда личность впервые пронизывает безличность бытия, а великий драматург, на века вперед создавший портретную галерею новой эпохи, скрывает лишь одно лицо - свое собственное» [8,11-12]. Интересно, что автор Предисловия тоже решил остаться анонимом, как будто пожелав быть хоть в какой-то мере аналогом своего великого персонажа.

Шекспир на портретах совсем не выглядит англичанином. Это тип лица южанина. Дух его произведений тоже не английский. Әто голос страстей и в то же время острого ума, А потому - благословим страсти! И поймем их. Любовь, которую мы положили в начале, не есть страсть, она изначальна, поскольку она есть Бог. А первое событие, восстание против нее, есть ревность, точнее, зависть к милости Бога, обращенной на другого. Это и есть ревность, которая страсть. И вся история, согласно первой главе Библии, в начале своем задана убий- ством. И вся она есть непрекращающиеся убийство. «Трудно бороться со страстью. Ибо цена ей жизнь» (Гераклит) [1, 564]. Или другой перевод: «Трудно бороться с сердцем. Ибо каждое из своих желаний оно покупает ценою души » [5, 303].

Ревность отнюдь не вырастает из чувства собственности, как иногда думают, или же из обманутого доверия, доверчивости. Она коренится в глубоком недоверии к своим собственным силам, разумеется, не физическим, другим силам. Ревность есть зависть к чужому существованию. Она - противник любви. Любви к самому себе. Если я тебя ревную к кому-либо, то это значит, что я полагаю лучшего, чем я, «другого», с кем, как я думаю, ты меня предаешь, как бы подражая первому событию истории (в любви или в каком-то ином отношении, дружбе, договоре или еще как-то). Ревность и обманутые ожидания - это не одно и то же. Ожидания всегда обманывают в сфере страстей и чувств. Это просто закон психической жизни. Получаешь не то, что ожидаешь. Ревность тоже часто обманывает (классический случай «Отелло», «Зимняя сказка»). Чаще даже бывает, что предательство есть, а ревности нет. Потому что чувство успевает раствориться, страсть угаснуть. Вся психологическая ситуация обесценивается, лишается смысла. Причем с обыденной точки зрения это хорошо, раз вы стали вновь в позицию равновесия, успокоения. Какое блаженство после свирепости страсти! Но это точка зрения, свойственная не только религии, аскезе, но и обыденной морали, не есть универсальная, даже не благотворная. Во всяком случае, это не очевидно. Страсти не суть зло для души, напротив. Они обладают очищающим и обучающим действием. По сути, это пограничная ситуация, в которой мобилизуются неведомые силы души. Гасить страсти и умерять чувства (навязывать им принятую в обществе меру) требует общение, удобство, комфорт взаимодействия людей в процессе общения. Этого требуют накатанные схемы общения. Превышение меры разрушит «колею» (о которой поет В. Высоцкий), а без превышения невозможно найти самого себя. В страсти есть превышение энергетического уровня, накал страстей - внутренний огонь - пылающее пламя. Вот этот огонь открывает, освещая, то, что мы изначально себя зна- 
ем (но забыли), и знаем себя от сотворения мира, ведь мы вместе с миром были и созданы, неразрушимо. Сколько совершается преступлений ради этой страсти, даже убийство. Идеально представленное в «Отелло» (комическое в определенном смысле разрешение сходной ситуации в «Зимней сказке», у Шекспира все и везде зеркалится, в самих пьесах и в отсылках между пьесами). Но, как и положено, смерть обоюдна, - небольшой отрезок времени отделяет одну смерть (жертвы) от другой (убийцы). Как и в «Ромео и Джульетте», но там без ревности - но смерть тоже обоюдна. То есть эти симметрии говорят что-то большее, нежели скорбная мысль о невозможности безмятежной и счастливой любви.

Яркий пример разотождествлений по поводу авторства это конечно, У.Шекспир. Кого только не предлагали в авторы. Например, Ф. Бэкона. На каком основании? Образованности, ума. Но надо быть совсем глухим, чтобы не почувствовать глубокой разница и по духу, и по природе между ними. Рассудительная ровная ментальность Бэкона, протопозитивиста, никак не согласуется с ментальностью нашего загадочного автора, исполненного южных страстей, прекрасно сочетающихся с гибким, ярким и даже отчасти пестрым умом. К тому же, что же Бэкон не участвовал в жизни театра и не проявлял особого интереса к якобы своему творчеству? И что же он для театра делал после 1616 г.? И даже после 1613 г., когда Шекспир отошел от лондонского театрального кружка, вернувшись в свой родной город? Ничего гениального нигде не появилось. Странно. Относительно других кандидатур тоже все гипотезы рассыпаются, и прежде всего потому, что Шекспир был человеком театра, знал актеров и жизнь театра изнутри. Это невозможно было в те времена ни для философов (к тому же в пьесах Шекспира полно насмешек над философией), ни для аристократов. Поэзия, сонеты, соревнования в классическом и возвышающем душу стиле - это достойно, а площадные шуточки и непристойности, без которых не обходится практически ни одна пьеса, - это не для них. К тому же образование было у Шекспира вполне достаточное, в Лондоне издавались и были распространены популярные книжки, он покупал также исторические хроники. А главное, тогда актерское мастерство це- нилось выше, чем авторство драматурга. И оплачивалось лучше. Авторского права вообще не было, разумеется. Текст резали и коверкали, приспосабливали к ситуации и желаниям покровителей. Все как всегда. Уильям Шекспир любил театр, и он им жил. Современники, его знавшие, высоко ценили его талант и как поэта, и как драматурга. Сомнения в авторстве есть черта, свойственная нашему времени, и причины этого разотождествления достаточно ясны. Это не только удаление от нас эпохи, исчезновение из нашего поля зрения многих особых ее черт, забывание. Мы и близкие к нам времена с трудом припоминаем, если вообще припоминаем. Все стирается временем. Умирает. И на эту, уже почти гладкую поверхность «прошлого» мы проецируем свои представления. Современной нам личности по сравнению с прошлыми эпохами не хватает объема, целостности. Но все же сам факт того, что творчество У.Шекспира со временем стало восприниматься как небывало огромное по мысли, сложности и многообразию, как оно не воспринималось в свое время, интересен. Нам представляется, что все это превосходит силы «простого смертного», и это заставляет искать более достойного (по нашим же критериям) кандидата на роль такого Шекспира. Сам этот факт, повторяем, интересен. Нам нужны достойные авторы, достойные того места, которые мы им хотим отвести. Достойные нашего восхищения и как личности, чтобы и личность была тоже выдающаяся, по нашим же представлениям. Хотя исторический, фактический, так сказать. Шекспир был вполне достойным человеком, его пресловутая мелочность вовсе не так уже непонятна. Не было денег, он потребовал возврата долга (небольшого), так ведь надо было сгоревший театр восстанавливать! Все как всегда. Завещание не понравилось, так на то оно и завещание, чтобы не блистать поэтической мыслью, иначе могут ведь и понять неправильно. Какие еще упреки высказывались в адрес этого человека? Что в доме и вещах его не было найдено никаких рукописей пьес. Так ведь пьесы, отданные для постановки в театре, становились собственностью театра. Да и вообще, уехав их Лондона, Шекспир перестал быть человеком театра, для него наступил конец игры. Это уже другой человек, что и смущает умы наших современников последние два века. 
Мне же кажется это естественным.

Шекспир автор именно в том смысле, что он был фокусом той среды и той энергии, которая высвободилась в тот самый момент и в то самое время, при том состоянии мира, отчасти на фоне веселого отчаяния, вызванного эпидемиями чумы, частыми в то время. особенно в Лондоне.

Лично мне самой симпатичной версией вероятного анонима, предлагаемого на роль Шекспира, представляется та, что якобы на самом деле тот был итальянцем. Эта версия, оказывается, была высказана уже давно, задолго до того, как она и мне пришла в голову. Итак, этот итальянец родился на Сицилии. У него было имя - Микельанджело Кролаланца. Спасаясь от инквизиции, он переехал в Англию и поменял фамилию $[8,11]$. Я не знаю аргументов автора этой версии. Мои аргументы были таковы. Темперамент автора комедий, трагедий, всех пьес вообще отнюдь не английский, это явно южный темперамент. Далее. Место действия очень часто выбирается именно Италия, причем колорит, нравы, говор, чувства, гибкость ума тоже совсем не английские, они - южные. Итальянские. «Я безумен только при норд-весте. Если же ветер с юга, я еще могу отличить сокола от цапли", - говорит Гамлет. Но почему же безумие с северо-запада? А здоровый разум с юга?

Далее. Автор обязательно, согласно моей гипотезе, прячется за каким-то персонажем. Каким же? очевидно, за Просперо из «Бури». Просперо - это имя означает «благоприятствовать». Это добрый волшебник, можно сказать, гуманист, владеющий благой магией. А разве автор для театра не есть тот, кто владей магией воссоздания целого замкнутого (как Просперо на своем острове) мира вне мира, волшебной голограммы всего и, в частности, каждого события в этом всём? Далее. Сам Просперо приплыл на корабле, потерпевшем крушение. Прозрачно. Откуда же можно прибыть на остров, как не с юга, из Венеции? И на своем острове от тоже принимает потерпевших кораблекрушение (актеров, то есть, участников в его магии). Но главное, что он принес традицию итальянского театра на площади, а сам этот театр на площади - и это моя вторая рискованна гипотеза - есть влияние суфизма с его парадоксами, отрицательным отношением к «философии» (фальсафа), которое персонифицируется в фигуре сэра Джона Фальстафа во многих пьесах и присутствует в знаменитых высказываниях (относительно того, что есть в мире много такого, что и не снилось вашей философии), коих достаточно. А также в так называемых непристойных шуточках.

Мне версия относительно итальянского присутствия в этом театре кажется вероятной. Но не обязательно итальянцем был фактическое лицо, Шекспир. Это могла быть часть труппы, это могли быть другие лица из этого театрального мира, прибывавшие в Англию на кораблях. Во всяком случае, сцена с «мышеловкой» может быть неким отдаленным свидетельством такой возможности, а в этой сцене есть еще один момент, относящийся к авторству. Там Гамлет просит вставить в пьесу 12 строк, которые помогут ему обличить короля в совершенном им преступлении. То есть и сам текст пьесы, вероятно, многих пьес частично включал строки отовсюду, импровизации самих актеров, иначе говоря, все как всегда.

На этом примере хороша видно, что автор почти всегда есть интегрированный в один голос хор множества персонажей. Мастерство автора в его способности к высшему синтезу всего, что ни подвернется ему под руку. Во всяком случае, это не некий маньяк, преследующий одну навязчивую идею, не одержимый горделивой заносчивостью, больным самолюбием; это ни в коем случае не психически больной человек. Нет, гений требует сверх здоровья. Гений способен удержать множества голосов, всего населения заколдованного острова, как Просперо, и выйти сухим из воды.

Теперь надо все-таки пояснить, что имеется в виду под словом «гений». Без всякой истории вопроса скажу, что для меня это некое относительно самостоятельное образование в тонком мире, которое может руководить мыслью и действием человека. Это не даймон, то есть не прирожденный каждому человеку дух, ведущий его по жизни, охраняющий его и тоже способный вдохновлять на благие дела, о котором говорил Платон. Это, конечно, не бес христианской религии, который, скорее, похож на психическую болезнь, одержание, крайнюю болезненную степень вожделения и страсти. Нет, это гений, который может считаться нормой здоровья. Однако эта норма не под 
силу современному составу человека, точнее, тому состоянию, в котором этот состав оказался. Поэтому мы охотно восхищаемся гением, не будучи в состоянии жить под его властью. Поэтому гениев единицы. Но каждый может оценить творения гениального человека в меру своей восприимчивости.

\section{$* * * * * * * * *$}

Errare humanum est... ergo mihi licet errare.

Возможно, что я ошибаюсь в моих гипотезах, но позволено же мне будет умалчивать о моем незнании. «Говорить посредством молчания - тоже значит говорить, знать посредством незнания - тоже значит знать» (Ле-цзы). Так говорил представитель Традиции, он этим обозначил искомое единство проявленного и непроявленного, тайного и явного, вечного и временного, Человека, Бога и Вселенной.

И как писал Новалис: «Дух приводит вечное доказательство самого себя » $[6,86]$. Так пусть же Дух подтвердит или опровергнет мои гипотезы!

\section{Библиография:}

1. Аристотель. Собр. соч. ы 4 т. Т.4. М., 1984.

2. Гоголь Н. В. Собр. соч. в 6-ти т. T. IV. М., 1937. С.160-162.

3. Ибн-Араби. Трактат о Единстве. Перевод abdul-Hâdi (1911). L'Identité suprême dans l'ésotérisme musulman». http://esprit-universel.over-blog.com/Publié par Abdoullatif (Mars 2013).

4. Мааковельский. А. О. Досократики. М., 1999

5. Кант И. Критика способности суждения. М., 1994.

6. Новалис. Фрагменты. «Дух приводит вечное доказательство самого себя» СПб., 2014.

7. Платон. Собр. Соч. в 4 т. Т. 2. М., 1993.

8. Шекспир У. Собр. соч. в 2 т. Т. І. На основе изданий Ф. А. Брокгауза и И. А. Ефрона, на русском и английском языках. Без указания времени и места издания.

9. Ясперс К. Философия Книга третья. Метафизика. М., 2014.

10. Coomaraswamy. Ananda K. Hindouisme et bouddhisme. Traduit de 1.anglais par René Allar et Pierre Ponsoye. Paris. 1943.

\section{References (transliterated):}

1. Aristotel'. Sobr. soch. y 4 t. T.4. M., 1984.

2. Gogol' N. V. Sobr. soch. v 6-ti t. T. IV. M., 1937. S.160-162.

3. Ibn-Arabi. Traktat o Edinstve. Perevod abdul-Hâdi (1911). L'Identité suprême dans l'ésotérisme musulman». http://esprit-universel.over-blog.com/Publié par Abdoullatif (Mars 2013).

4. Maakovel'skii. A. O. Dosokratiki. M., 1999

5. Kant I. Kritika sposobnosti suzhdeniya. M., 1994.

6. Novalis. Fragmenty. «Dukh privodit vechnoe dokazatel'stvo samogo sebya» SPb., 2014.

7. Platon. Sobr. Soch. v 4 t. T. 2. M., 1993.

8. Shekspir U. Sobr. soch. v 2 t. T. I. Na osnove izdanii F. A. Brokgauza i I. A. Efrona, na russkom i angliiskom yazykakh. Bez ukazaniya vremeni i mesta izdaniya.

9. Yaspers K. Filosofiya Kniga tret'ya. Metafizika. M., 2014.

10. Coomaraswamy. Ananda K. Hindouisme et bouddhisme. Traduit de 1.anglais par René Allar et Pierre Ponsoye. Paris. 1943. 